\title{
BIOASSAY METHOD FOR TOXICITY STUDIES OF INSECTICIDE FORMULATIONS TO Tuta absoluta (MEYRICK, 1917)
}

\author{
Metodologia de bioensaio para estudos de toxicidade de formulações \\ comerciais de inseticidas a Tuta absoluta (Meyrick, 1917)
}

\author{
Tarcísio Visintin da Silva Galdino ${ }^{1}$, Marcelo Coutinho Picanço ${ }^{2}$, Elisangela Gomes Fidelis de Morais ${ }^{3}$, \\ Nilson Rodrigues Silva ${ }^{2}$, Geverson Aelton Rezende da Silva², Mayara Cristina Lopes ${ }^{2}$
}

\begin{abstract}
Chemical control is the main method for controlling the tomato leafminer, Tuta absoluta (MEYRICK, 1917) (Lepidoptera: Gelechiidae). Reported techniques for the evaluation of insecticide toxicity to the tomato leafminer are not in agreement with field conditions and do not allow us to verify whether doses used in the field are efficient for control. Thus, the objective of this work was to develop a bioassay methodology to study the toxicity of insecticide formulations to T. absoluta that represent field conditions for fast-acting insecticides (neurotoxics and inhibitors of respiration) and slow-acting insecticides (Bacillus thuringiensis and insect growth regulators). The leaf-dip method was the most efficient method for toxicity studies of insecticides formulations to T. absoluta. We verified that bioassays with fast-acting insecticides should be performed with glass Petri dishes containing one tomato foliole from the $4^{\text {th }}$ leaf from the plant apex infested with 10 larvae of $3^{\text {rd }}$ instar and these bioassays can last 48 hours. Conversely, bioassays with slow-acting insecticides should be performed with two-liter transparent PET bottles containing the $4^{\text {th }}$ leaf from the plant apex, with their petioles immersed in a glass bottle containing $120 \mathrm{~mL}$ of water, and this leaf should be infested with 10 larvae of $2^{\text {nd }}$ instar and this bioassays can last seven days.
\end{abstract}

Index terms: Susceptibility, tomato leafminer, chemical control, bioassay standardization, resistance survey.

\section{RESUMO}

O principal método utilizado no controle da traça-do-tomateiro Tuta absoluta (MEYRICK, 1917) (Lepidoptera: Gelechiidae) é a aplicação de inseticidas. As técnicas atuais de avaliação da toxicidade de inseticidas sobre essa praga não simulam a situação de campo e não possibilitam a verificação se as doses usadas no campo são eficientes no seu controle. Assim, neste trabalho, objetivouse desenvolver uma metodologia que represente as condições de campo para inseticidas de ação rápida (neurotóxicos e inibidores respiratórios) e de ação lenta (Bacillus thuringiensis e reguladores de crescimento. A metodologia mais eficiente para estudos de toxicidade de formulações comerciais a T. absoluta foi a imersão de folhas em calda inseticida. Para os bioensaios de inseticidas de ação rápida, sugere-se que estes sejam realizados em placas de Petri, contendo folíolos de tomate da $4^{\text {a }}$ folha a partir do ápice da planta, infestados com 10 larvas de $3^{\circ}$ ínstar e eles podem durar 48 horas. Quanto aos bioensaios de toxicidade de inseticidas de ação lenta, sugere-se que sejam realizados em garrafas PET transparentes, de dois litros, contendo a $4^{\mathrm{a}}$ folha de tomate a partir do ápice da planta infestada com 10 larvas de $2^{\circ}$ ínstar e seu pecíolo inserido em vidro de $120 \mathrm{~mL}$ contendo água. Nesse caso, o bioensaio pode durar sete dias sem prejuízo na eficiência.

Termos para indexação: Suscetibilidade, traça-do-tomateiro, controle químico, padronização de bioensaio, levantamento de resistência.

(Received in september 23, 2010 and approved in february 8, 2011)

\section{INTRODUCTION}

The tomato leafminer Tuta absoluta (MEYRICK, 1917) (Lepidoptera: Gelechiidae) originates from South America (GIORDANO; SILVA, 1999) and was recently introduced in Europe and North Africa (GARCIA; VERCHER, 2010). This insect is a serious tomato pest, because its larvae mine the leaves and bore not only fruits but also stems (PICANÇO et al., 1998 e 2007). Chemical control is the main control method towards T. absoluta (SIQUEIRA et al., 2000ab).
Two kinds of insecticides are used for T. absoluta control: fast-acting and slow-acting. The fast-acting insecticides are neurotoxics or respiration inhibitors. They kill larvae two days after the application, including the last instars that are more tolerant to insecticides (LIU et al., 2002; WANG et al., 2009). The slow-acting insecticides are Bacillus thuringiensis toxins and insect growth regulators. They usually kill larvae of early instars in at least five days (FISK; WRIGHT, 1992; SILVA et al., 2003).

${ }^{1}$ Universidade Federal de Viçosa/UFV - Departamento de Biologia Animal/DBA - Entomologia - Avenida Peter Henry Rolfs, s/n, Campus Universitário 36570-000 - Viçosa, MG - tarcsilva@gmail.com

${ }^{2}$ Universidade Federal de Viçosa/UFV - Departamento de Biologia Animal/DBA - Viçosa, MG

${ }^{3}$ Empresa Brasileira de Pesquisa Agropecuária/ Embrapa Roraima - Boa Vista, RR 
Insecticide efficiency is evaluated by toxicity bioassays. The purpose of these bioassays is to select new biological or organosynthetic insecticides and their most appropriate doses that affect insects, as well as to test pest resistance (SIQUEIRA et al., 2000) and the pesticide selectivity to natural enemies (PICANÇO et al., 2000; BACCI et al., 2009).

The standard technique used in toxicity bioassays is leaf immersion. This technique allows the product to be evenly distributed on the leaf surface and makes it possible to check whether or not the field doses are effective for the pest control (BACCI et al., 2009). The few studies of insecticide toxicity with $T$. absoluta have been carried out via topical application on the insects' bodies (LIETTI et al., 2005) or by putting the insects into contact with filter papers impregnated with insecticide molecules (SALAZAR; ARAYA, 1997 e 2001; SIQUEIRA et al., 2000ab). These techniques do not represent field situations and do not allow us to verify whether doses are being applied efficiently (BACCI et al., 2009).

Therefore, the goal of this work was to develop a bioassay methodology to study the toxicity of insecticide formulations on $T$. absoluta that corresponds to field conditions for both fast-acting and slow-acting insecticides.

\section{MATERIAL AND METHODS}

Bioassays were performed at the Pest Management Laboratory from Federal University of Viçosa. Five experiments were carried out to determine the most appropriate methodology for toxicity bioassays of insecticides to $T$. absoluta. The bioassay conditions were: temperature $25 \pm 1^{\circ} \mathrm{C}$, a photoperiod of 12 hour light and relative humidity $75 \pm 5 \%$. The tomato leaves used in the bioassays were collected from plants of the "Santa Clara" cv. two months after the seedlings were transplanted, when they presented about nine leaves. These plants were cultivated according to recommendations by Silva e Vale (2007). The experiments were carried out in a completely randomized design.

\section{Defining where leaves for bioassays should be collected}

The leaves used in this experiment were cut from the first to the ninth node of the plant from the stem apex. Therefore, there were nine treatments (nine kinds of leaves from different plant nodes) and ten repetitions of each. Tomato leaves (with their petioles) were kept in ambar vials containing $120 \mathrm{ml}$ of water. The color and the turgidity of leaves were evaluated daily for a period of one week. Five scores were accredited to these characteristics. The scores for leaf color were: 1 = light yellow, $2=$ yellow intense, $3=$ yellow, $4=$ beginning of yellowing and $5=$ green. The scores for the leaves turgidity were: $1=$ dry, $2=$ intense wilt, $3=$ wilt, $4=$ beginning of wilting and $5=$ turgid. A paired $t$-test was used to verify whether the leaves remained green or turgid (maximum scores) over the bioassay evaluation time.

\section{Defining the method of supplying water to the leaf}

In previous experiments, the $4^{\text {th }}$ node from the stem apex has been shown to offer the best leaf to use for testing. $4^{\text {th }}$ node leaves were used in bioassays of insecticide toxicity towards T. absoluta. Two recipients were used: glass Petri dishes (9 $\mathrm{cm}$ diameter and $2 \mathrm{~cm}$ height) and two-liter transparent PET bottles. These recipients are standard containers used in bioassays of insecticide toxicity (TRAN et al., 2005, BACCI et al., 2007).

For the Petri dish method, a whole tomato foliole was used because there was enough space for it. Three treatments with the Petri dishes were carried out: 1 ) one tomato foliole inside the Petri dish, 2) one tomato foliole and one water-damped cotton and 3) one tomato foliole with its base wrapped by water-damped cotton in aluminum foil.

For the PET bottle method, full tomato leaves from the plant apex were transferred to bottles. Four treatments with PET bottles were also carried out: 1) one tomato leaf inside the PET bottle, 2) one tomato leaf and one waterdamped cotton, 3) one tomato leaf with its petiole wrapped by water-damped cotton in aluminum foil and 4 ) one tomato leaf with its petiole immersed in an ambar vial containing $120 \mathrm{ml}$ of water. The same evaluations on leaf color and turgidity as well as statistical analysis were carried out of according to the results of the previous experiment.

\section{Method of adding T. absoluta to the recipients}

This experiment was carried out in the same recipients as described above. According to previous experiment outcomes, it was chosen the Petri dishes with one tomato foliole and the PET bottles with one tomato leaf with its petiole immersed in ambar vials containing 120 $\mathrm{mL}$ of water for both fast-acting and slow-acting insecticides, respectively.

The larvae and eggs of T. absoluta used in this experiment were from a mass-rearing colony maintained at the Pest Management Laboratory from the Federal University of Viçosa since 2002 and reared according to Leite et al. (1998).

For Petri dish method, tomato folioles were infested with $T$. absoluta larvae at the $3^{\text {rd }}$ and $4^{\text {th }}$ instar, because 
these instars are usually more tolerant to fast-acting insecticides (LIU et al., 2002; WANG et al., 2009). For the PET bottle method, leaves were infested with eggs and larvae at the $1^{\text {st }}$ and $2^{\text {nd }}$ instar, because the response to slow-acting insecticides in these stages is higher (FISK; WRIGHT, 1992; SILVA et al., 2003). The larvae were transferred to the folioles or leaves with a thin brush. Larvae survival was assessed daily for a period of one week. The time spent establishing and performing the experiment was recorded.

T. absoluta survival data were compared with the values 80 and $90 \%$ (of survival) by $t$ test at $\mathrm{p}<0.05$, because 80 and $90 \%$ are the minimum and ideal survival rates respectively for the control in bioassays of insecticide toxicity (ROBERTSON et al., 2007). The time spent establishing and performing the experiment was subjected to a variance analysis and the treatment averages were compared by Tukey's test at $\mathrm{p}<0.05$.

\section{Comparison of the main methods used for toxicity bioassays of insecticide formulations to T. absoluta}

The time and cost of performing six repetitions of the main methods (leaf-dip, potter spray tower, filter paper and topical application) used in toxicity bioassays of insecticides were calculated. The maximum exposure of larvae of T. absoluta to insecticide formulations using the filter paper impregnation method was also calculated. This experimental design was completely randomized with four replications. The treatments were larvae of $2^{\text {nd }}$ and $3^{\text {rd }}$ instar (stages that are ideal for toxicity bioassays). Each experimental unit consisted of a glass petri dish $(9.5 \mathrm{~cm} \times 2.0 \mathrm{~cm})$ containing one filter paper disc and 10 larvae. Mortality was evaluated every 30 minutes. The maximum exposure of larvae to insecticides formulations using the filter paper impregnation method was one in which the larvae survival was greater than $80 \%$ (minimum survival for toxicity bioassays) (ROBERTSON et al. 2007).

\section{Efficiency of selected bioassay methodology}

Toxicity bioassays were carried out with T. absoluta populations both susceptible (Viçosa, Minas Gerais State, Brazil 2045'14"S, 42 '52'55'W) and resistant (Camocim de São Felix, Pernambuco State, Brazil 08²1'32"S, $35^{\circ} 45^{\prime} 43^{\prime \prime} \mathrm{W}$ ) to insecticides. Larvae of $T$. absoluta used in this experiment were also from a mass-rearing colony. Two insecticides were used in the bioassays, permethrin 500EC, a fast-acting insecticide and the diflubenzuron 250WP, a slow-acting insecticide. Bioassays using both insecticides were carried out based on aforementioned results using
Petri dishes containing one tomato foliole and PET bottles containing one tomato leaf with the petiole immersed in a glass bottle, respectively.

Tomato folioles and leaves were dipped for ten seconds into the insecticide solution and water (control). Sodium n-dodecyl benzene sulfonate 320EC was added as spreader at $0,2 \mu \mathrm{L} / \mathrm{mL}$ final concentration to both insecticide solution and water. After drying at room temperature, tomato folioles were transferred into Petri dishes or PET bottles, depending on the insecticide action. Tomato folioles (within Petri dishes) were infested with ten $3^{\text {rd }}$-instar larvae and tomato leaves (within PET bottles) were infested with ten $2^{\text {nd }}$-instar larvae, as determined in the previous experiments for knowing the appropriate size of $T$. absoluta larvae. Insect mortality from Petri dishes assays was assessed after 48 hours of exposure, while that from PET bottles was assessed after one week of exposure. The insects were considered dead if they were unable to walk when prodded with a fine paint brush.

Six to ten concentrations of each insecticide were used, besides the control that comprised only water (to correct for natural mortality) according to Abbotts formula (ABBOTT, 1925). Four replicates were used for each insecticide concentration and bioassays carried out following a completely randomized design.

Concentration-mortality results were subjected to a Probit analysis correcting the data for natural mortality (PROC PROBIT) (SAS Institute 2001). The 50\% lethal concentrations $\left(\mathrm{LC}_{50}\right)$ were obtained from concentrationmortality curves. The resistance ratios $\left(R_{50}\right)$ were calculated using the formula: $\mathrm{RR}_{50}=\mathrm{LC}_{50}$ of population for the insecticide/ $\mathrm{LC}_{50}$ of the most susceptible population to an insecticide. The $95 \%$ fiducial intervals of the $\mathrm{LC}_{50}$ and of the $\mathrm{RR}_{50}$, at probability of $95 \%$, were calculated according to PROBIT from SAS program (SAS Institute 2001). The $\mathrm{LC}_{50}$ or the $\mathrm{RR}_{50}$ was considered similar to other when it was inside the fiducial interval of this characteristic.

\section{RESULTS AND DISCUSSION}

The leaves detached from the first up to the seventh node from the stem apex remained green during the course of the seven-day bioassays. The seventh and eighth node leaves were not green after seven and five days of setting up the experiment, respectively. The ninth-node leaves were already yellowing when they were collected from the plant (Figure 1A).

The first to seventh node leaves from the stem apex remained turgid throughout the bioassay. The eighth and 
ninth node leaves were not turgid in the seventh and fifth days after setting up experiment, respectively (Figure 1B). Therefore, the best leaves to bioassay the insecticides toxicities towards T. absoluta were those detached from the first to sixth node from the apex in the plant and thus, the experiment could last up to six days. These leaves may be appropriate for bioassays because they were already expanded and had not started their senescence, therefore retaining nutritional reserves that allow the leaves to remain green and turgid for seven days (KARUPPANAPANDIAN 2008). Furthermore, these leaves appear to have provided an adequate quantity of nutrients to T. absoluta larvae during the bioassays (PETER 1991, MEYER; ROOT 1996).

In the insecticide bioassays with Petri dishes, the folioles without the water supply (i.e., only one foliole inside of Petri dishes) remained green and turgid during four days. Although, folioles supplied with water were still green and turgid on the seventh day (Figure 1C), water droplets formed on the inner wall of Petri dishes because of excessive humidity. Therefore, by performing these bioassays, no water supply to the folioles was necessary because the bioassays took only two days (LIU et al., 2002; WANG et al., 2009), and without a water supply, the folioles stayed in a good conditions for four days. The leaves stayed turgid for seven days only if they were with their petioles immersed in a glass bottle with water (Figura 1D). Therefore, if using PET bottles to bioassays $T$. absoluta, the leaves should be supplied with water with their petioles immersed in a glass bottle and the bioassays can last for seven days.

In the treatment where leaves were infested with eggs, the insect survival was less than $80 \%$ from the
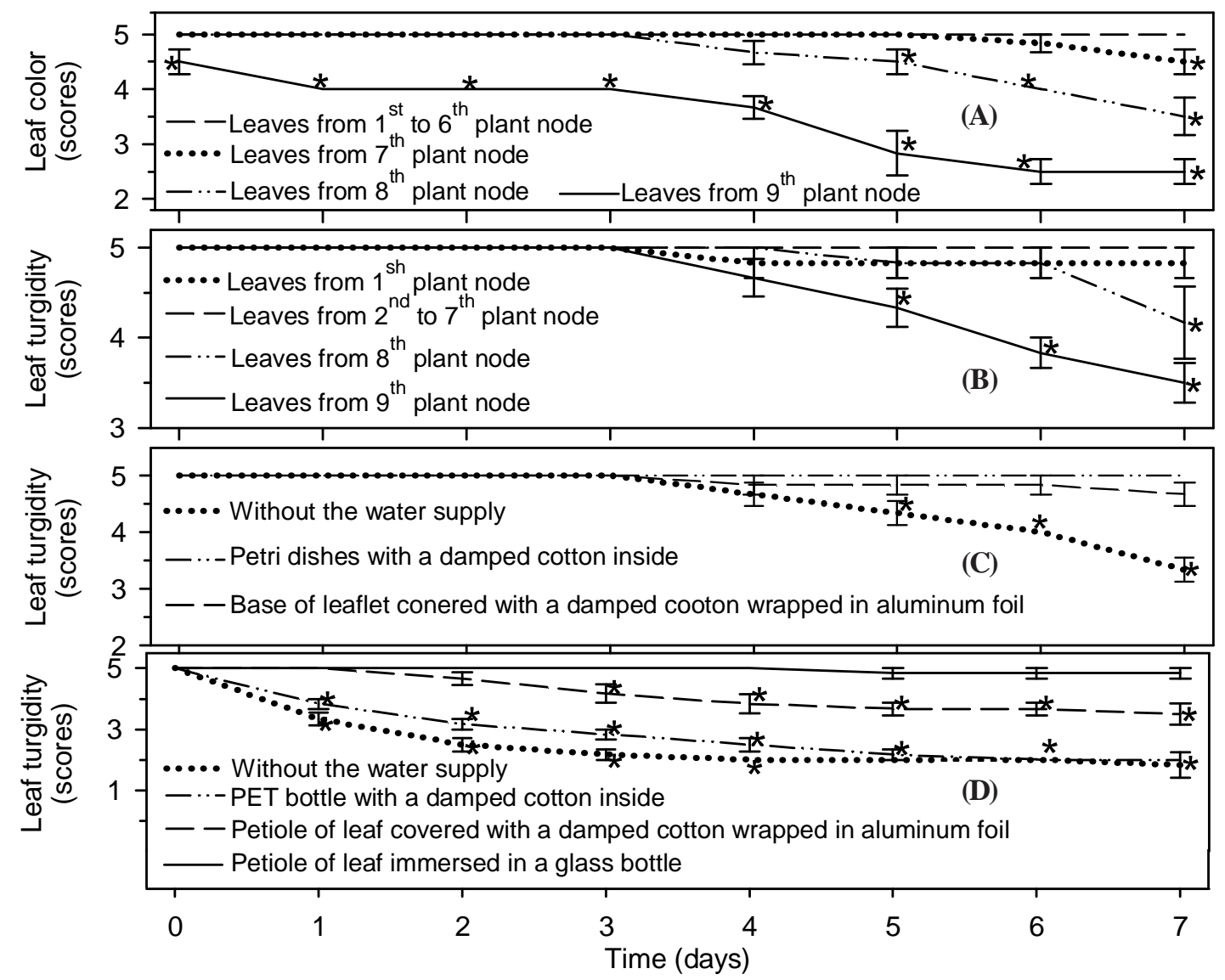

Figure 1 - Color (A) and turgidity (B) of tomato leaves cut from different plant nodes. (C) and (D) Turgidity of tomato leaves in different method of water supply over the evaluation time of bioassay with Petri dishes (C) and PET bottles (D). * Color or turgidity of tomato leaves was different of green or turgid by paired t-test at $\mathrm{p}<0.05$. The scores for the leaves color were: $1=$ light yellow, $2=$ yellow intense, $3=$ yellow, $4=$ beginning of yellowing and $5=$ green. The scores for the leaves turgidity were: $1=$ dry, $2=$ intense wilt, $3=$ wilt, $4=$ beginning of wilting and $5=$ turgid.

Ciênc. agrotec., Lavras, v. 35, n. 5, p. 869-877, set./out., 2011 
second day after starting the bioassays, when actually the eggs had hatched (Figure 2A). In the leaves infested with $1^{\text {st }}$ instar larvae, the insect survival was higher than $90 \%$ and $80 \%$ until the third and fourth day respectively from bioassay beginning (Figure 2B). In the leaves infested with $2^{\text {nd }}$ instar larvae, the insect survival was higher than $90 \%$ throughout the bioassay (Figure 2C).

According to these results, $2^{\text {nd }}$ instar larvae should be used to bioassay T. absoluta with slow-acting insecticides. These conclusions were based on larvae survival (higher than 90\%), since this survival rate is ideal in toxicity bioassays (ROBERTSON et al. 2007).

In the treatments where the leaves were infested with $3^{\text {rd }}$ and $4^{\text {th }}$ instar larvae, the insect survival was higher than $90 \%$ throughout the bioassay. The larvae turned into pupae on the sixth and third day, when $3^{\text {rd }}$ and $4^{\text {th }}$ instars were respectively placed on the leaves (Figures 2D and 2E).

According to these results, larvae of T. absoluta up to the $3^{\text {rd }}$ instar may be used in toxicity bioassays with fastacting insecticides. Leaf infestation with $3^{\text {rd }}$ instar larvae is more appropriate because besides the insect survival rate being higher than $90 \%$, the larvae were exposed to insecticide at least four days before they turned into pupae. This exposure time is appropriate because the bioassays with fast-acting insecticides must last at least two days. On the other hand, despite survival being higher than $90 \%$ in treatments where the leaves were infested with $4^{\text {th }}$ instar larvae, if the larvae are placed on the leaves at the end of this stage, they turn into pupae in at least a day. Third and fourth instar larvae of $T$. absoluta should not be used in toxicity bioassays with slowacting insecticides, because these bioassays must last at least four days, and according to the results of this work, larvae in these instars turn into pupae before this time.

The time spent establishing and evaluating the bioassays with slow-acting insecticides was higher when the leaves were infested with eggs than with $1^{\text {st }}$ and $2^{\text {nd }}$ instar larvae (Figure 3A). This occurred because of the difficulties during the transfer of eggs and mortality counts. The time spent establishing the experiment with fast-acting insecticides was similar to the time spent when the leaves were infested with larvae of $3^{\text {rd }}$ or $4^{\text {th }}$ instar. The time evaluating the experiment was less when the leaves were infested with $3^{\text {rd }}$ instar larvae than when the leaves were infested with $4^{\text {th }}$ instar larvae (Figure 3B). Since fourth instar larvae have low mobility, it is difficult to ascertain whether they are dead or not.
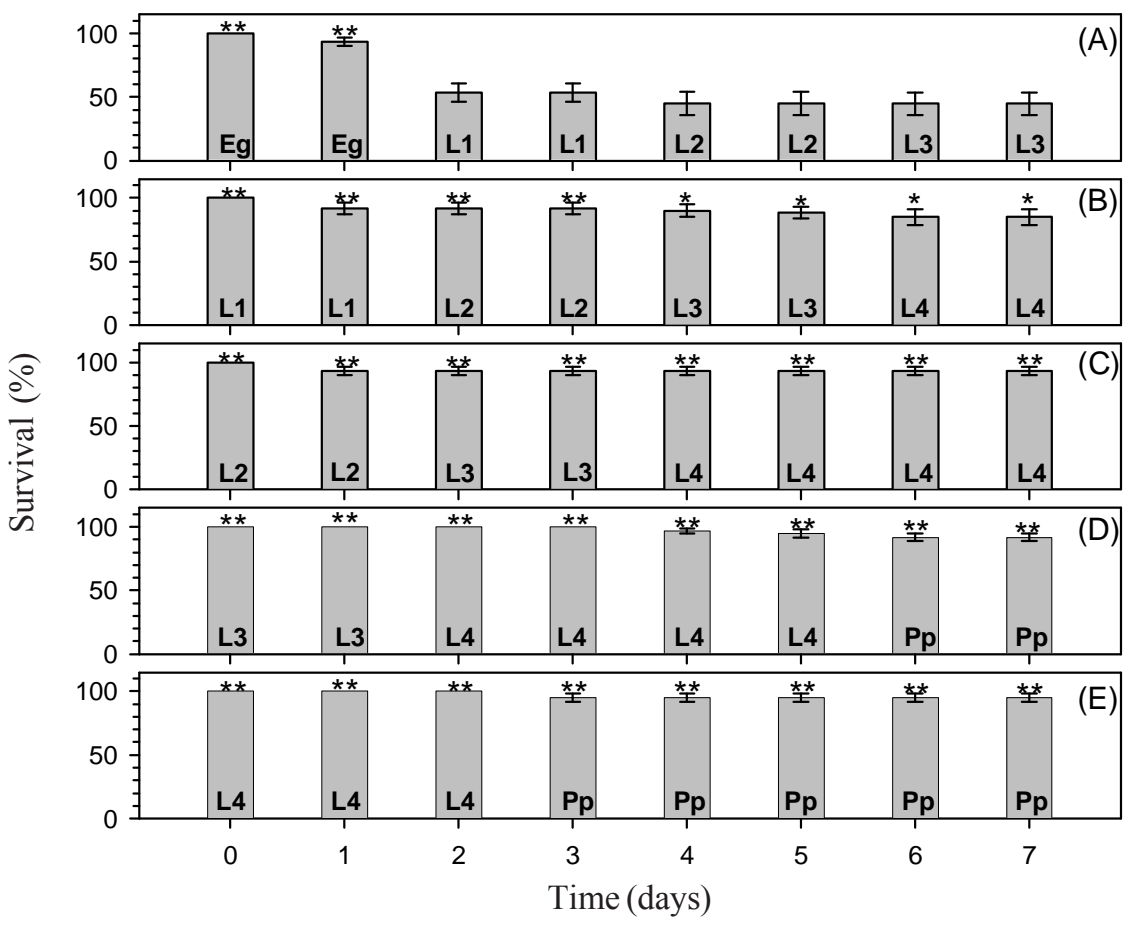

Figure 2 - Tuta absoluta survival in bioassays using infested leaves with eggs (A), larvae of first (B), second (C), third (D) and fourth (E) instar. * and ** Survival higher than $80 \%$ or $90 \%$ by $t$ test at $p<0.05$, respectively. Eg $=$ egg, L1, L2, L3 e L4 = larvae of $1^{\text {st }}, 2^{\text {nd }}, 3^{\text {rd }}$ and $4^{\text {th }}$ instar and $\mathrm{Pp}=$ pupae. Vertical barrs $=$ standard error. 


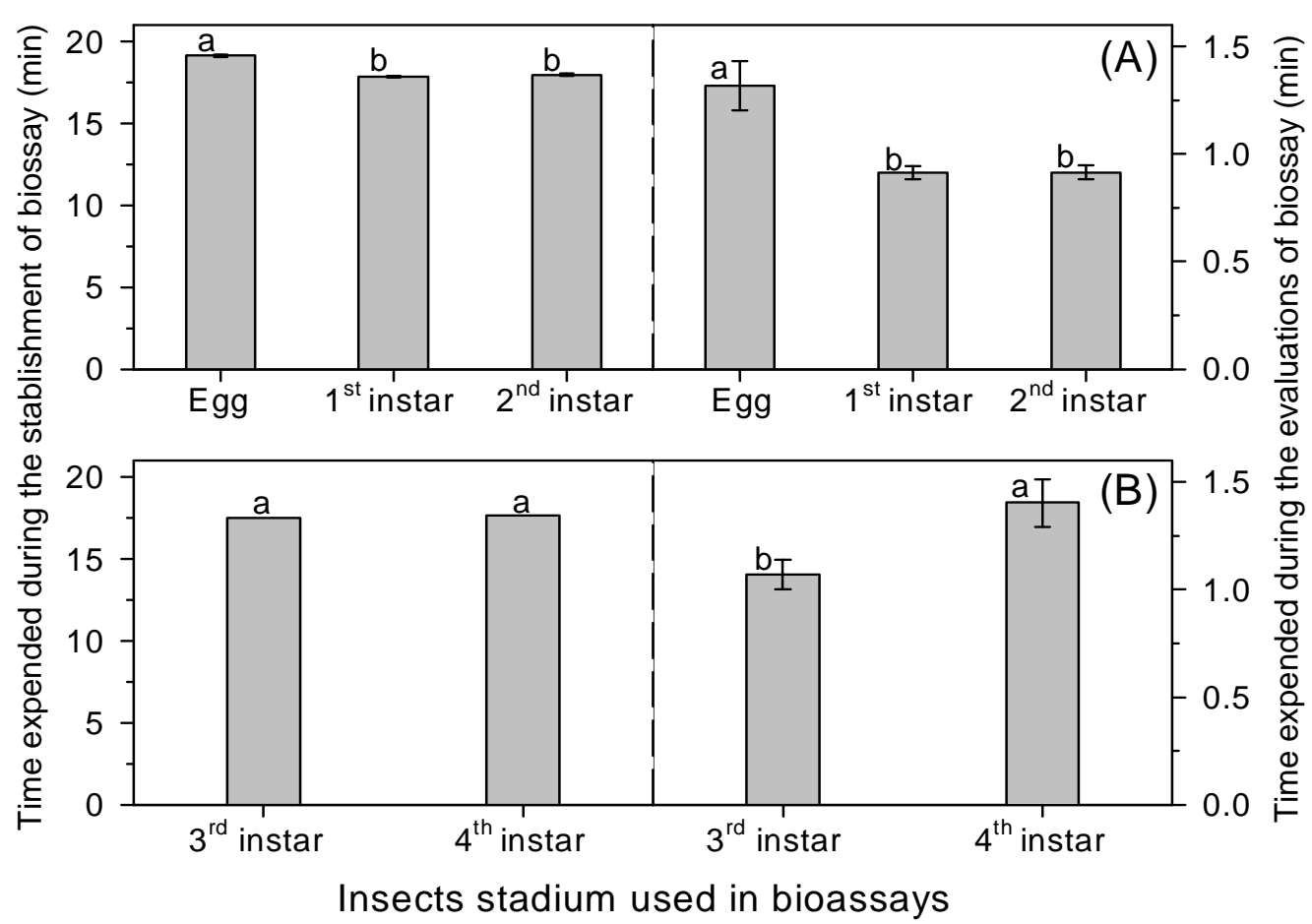

Figure 3 - Time expended during the establishment and the evaluations of bioassays with (A) slow-acting insecticides using folioles infested with eggs, larvae of first and second instar and with (B) fast-acting insecticides using leaves infested with larvae of third and fourth instar of Tuta absoluta. Histograms with the same letter do not significantly differ by the Tukey test $(\mathrm{p}<0.05)$. Vertical barrs $=$ standard error.

In toxicity bioassays using the filter paper impregnation method, the maximum exposure of $T$. absoluta to insecticides was five or six hours for larvae of $3^{\text {rd }}$ and $2^{\text {nd }}$ instar, respectively (Figure 4). This low exposure time of insects to insecticides limits the use of this methodology in toxicity bioassays of insecticide formulations to T. absoluta as many products take several days to express their toxicities (LIU et al., 2002; WANG et al., 2009). The low exposure period meant it was not possible to verify if the insecticide is failing to control T. absoluta in the field. Insecticide toxicity is a function of the exposure time of the insect to the molecule. Therefore, the mortalities caused by the insecticide to T. absoluta in field should be much higher than when the product is applied on filter paper. This information is essential to the management of insect resistance to insecticides.

Leaf-dip and topical application methods had lower costs and took less time to perform (Figure 5). However, the topical application method can not be used in toxicity bioassays of insecticide formulations, because most of these formulations are not soluble in the solvent used in this method (i.e. acetone). The potter spray tower method has a slow execution time and a high initial cost, due to the necessity of purchasing equipment. Thus the ideal method for studying the toxicity of insecticide formulations to $T$. absoluta was the leaf-dip bioassay.

The Probit model fitted to all the concentrationmortality data obtained from bioassays of insecticides tested towards T. absoluta populations performed according to the aforementioned methodology (Chisquare test at $\mathrm{p}>0.05$ ). The $\mathrm{LC}_{50}$ estimate for the Viçosa population (susceptible) was lower than that for Camocim de São Félix population (resistant), both for permethrin or for diflubenzuron. Regarding diflubenzuron, the slope of the concentration-mortality curve for Camocim de São Félix population was lower than that for the Viçosa population. For the permethrin, the slope of concentration-mortality curves for both populations were similar (Table 1). These results show that the selected methodology is appropriated for these kinds of bioassays because with it was possible to estimate the concentration-mortality curves for both evaluated insecticides. 


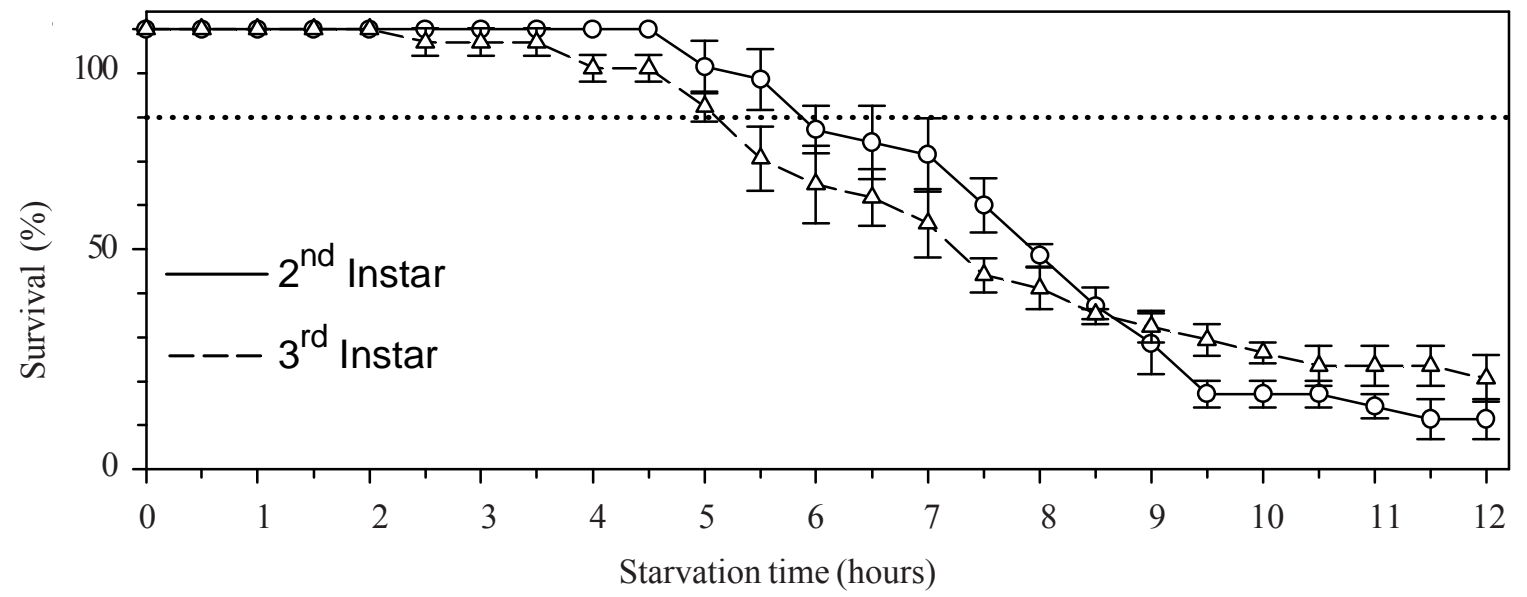

Figure 4 - Survival of Tuta absoluta larvae in function of starvation time. Vertical barrs $=$ standard error.

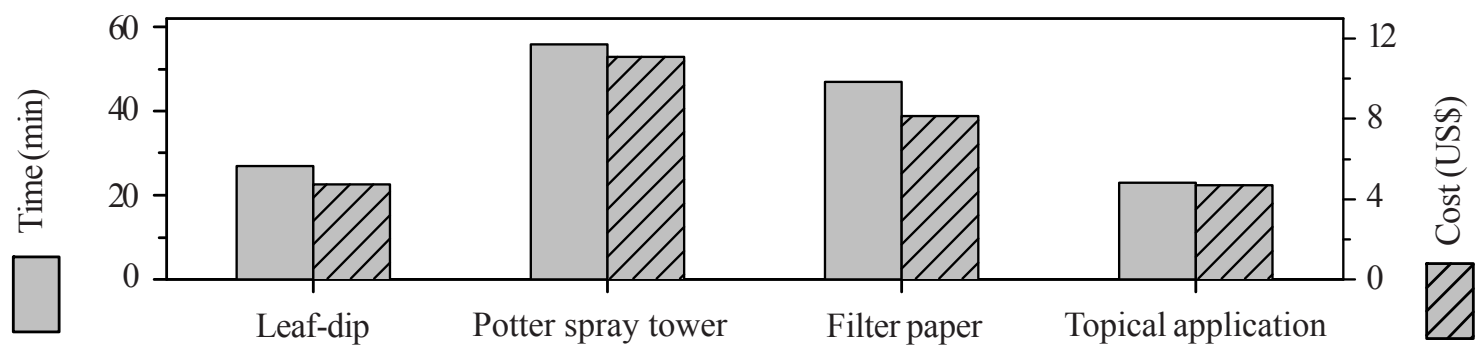

Bioassay methodology

Figure 5-Times and costs for completion of six repetitions of the main methods used in toxicity bioassays of insecticides to Tuta absoluta.

Table 1 - Relative toxicity of the insecticides diflubenzuron 250WP and permethrin 500EC to larvae of Tuta absoluta populations (Pop) of Viçosa (Vi) and Camocim de São Félix (Ca).

\begin{tabular}{|c|c|c|c|c|c|c|c|}
\hline Pop & $\mathrm{N}^{*}$ & Slope $\pm \mathrm{CI}_{95 \%}$ & $\mathrm{LC}_{50}\left(\mathrm{FI}_{95} \%\right) \mu \mathrm{g}$ a.i. $/ \mathrm{mL}$ & $\mathrm{RR}_{50}\left(\mathrm{FI}_{95 \%}\right)$ & $\mathrm{LC}_{95}\left(\mathrm{FI}_{95 \%}\right) \mu \mathrm{g}$ a.i. $/ \mathrm{mL}$ & $\chi^{2}$ & $\mathrm{P}$ \\
\hline \multicolumn{8}{|c|}{ Diflubenzuron - Larvae of $2^{\text {nd }}$ instar } \\
\hline $\mathrm{Vi}$ & 260 & $1.80 \pm 0.36$ & $842.64(598.03-1070)$ & $1.00(0.67-1.49)$ & $6843(3957-22753)$ & 2.07 & 0.56 \\
\hline $\mathrm{Ca}$ & 300 & $1.17 \pm 0.15$ & $20543(13199-30609)$ & $13.39(8.25-21.73)$ & $513334(259657-1493826)$ & 0.92 & 0.82 \\
\hline \multicolumn{8}{|c|}{ Permethrin - Larvae of $3^{\text {rd }}$ instar } \\
\hline $\mathrm{Vi}$ & 199 & $1.06 \pm 0.12$ & $59.01(36.05-92.48)$ & $1.00(0.52-1.91)$ & $2068(1016-5895)$ & 2.95 & 0.40 \\
\hline $\mathrm{Ca}$ & 281 & $1.29 \pm 0.14$ & $736.31(534.93-1309)$ & $12.48(7.14-21.80)$ & $13800(7469-34292)$ & 2.75 & 0.74 \\
\hline
\end{tabular}

$\mathrm{N}^{*}=$ total number of insects used in bioassay, $\mathrm{CI}=$ confidence interval, $\mathrm{LC}=$ letal concentration, $\mathrm{FI}=$ fiducial interval, $\mathrm{RR}=$ resistance ratio $=\mathrm{LC}_{50}$ of resistant population $/ \mathrm{LC}_{50}$ of susceptible population. a.i. = active ingredient.

\section{CONCLUSION}

The most efficient methodology to study the toxicity of insecticide formulations to T. absoluta is leafdip. The bioassays to study the toxicity of fast-acting insecticides towards T. absoluta may be performed with Petri dishes containing one tomato foliole detached from the $4^{\text {th }}$ plant node from the stem apex. The foliole used in these bioassays should be infested with $103^{\text {rd }}$ instar larvae and the experiment can last 48 hours. On the other hand, the toxicity bioassays with T. absoluta using slow-acting insecticides may be performed with two-liter transparent PET bottles containing one tomato leaf cut from the $4^{\text {th }}$ 
plant node from the stem apex and the leaf petioles must be immersed in a glass bottle containing $120 \mathrm{~mL}$ of water. These leaves may be infested with $102^{\text {nd }}$ instar larvae and the bioassays can last seven days.

\section{ACKNOWLEDGMENTS}

We thank the Brazilian branch of the Insecticide Resistance Action Committee (IRAC-BR), the National Council of Scientific and Technological Development $(\mathrm{CNPq})$, the CAPES Foundation (Brazilian Ministry of Education) and the Minas Gerais State Foundation for Research Aid (FAPEMIG) for the financial support.

\section{REFERENCES}

ABBOTT, W.S. A method of computing the effectiveness of an insecticide. Journal of Economic Entomology, Riverside, v.18, n.1, p.265-266, 1925.

BACCI, L. et al. Toxicity of insecticides to the sweetpotato whitefly (Homoptera: Aleyrodidae) and its natural. Pest Management Science, New York, v.63, n.7, p.699-706, 2007.

BACCI, L. et al. Physiological selectivity of insecticide to predatory wasps (Hymenoptera: Vespidae) of Diamondback moth. Sociobiology, Chico, v.53, n.1, p.151$167,2009$.

FISK, T.; WRIGHT, D.J. Response of Spodoptera exempta (Walk) larvae to simulated field spray applications of acylurea insect growth-regulators with observations on cuticular uptake of acylureas. Pesticide Science, New York, v.35, n.4, p.321-330, 1992.

GARCIA, M.F.; VERCHER, R., Descripción, origin y expansión de Tuta absoluta (Lepidoptera; Gelechiidae). Phytoma, Paradis, v. 20, p.16-20, 2010.

GIORDANO, L.; SILVA, C. Hibridação em tomate. In: (Ed.). Hibridação artificial de plantas. Viçosa-MG, 1999. Hibridação em tomate, p.463-480.

KARUPPANAPANDIAN, T. et al. Mechanism, control and regulation of leaf senescence in plants. Journal of Plant Biology, v.35, n.3, p.14, 2008.

LEITE, G.L.D. et al. Oviposicion y mortalidad de Tuta absoluta en Lycopersicon hirsutum. Manejo Integrado de Pragas, v.22, n.1, p.26-34, 1998.
LIETTI M.M.M.; BOTTO, E.; ALZOGARAY, R.A. Insecticide resistance in Argentine populations of Tuta absoluta (Meyrick) (Lepidoptera: Gelechiidae).

Neotropical Entomology, Vacaria-RS v.34, p.113-119, 2005.

LIU, T.X. et al. C. Toxicity, persistence, and efficacy of indoxacarb on Cabbage looper (Lepidoptera: Noctuidae) on cabbage. Journal of Economic Entomology, v.95, n.2, p.360-367, 2002.

MEYER, G.A.; ROOT, R.B. Influence of feeding guild on insect response to host plant fertilization. Oxford, ROYAUME-UNI: Blackwell Science, v.21, 1996

PICANÇO, M.C. et al. J.C. Effect of integrated pest management practices on tomato production and conservation of natural enemies. Agricultural and Forest Entomology, v.9, n.4, p.327-335, 2007.

PICANÇO, M.C.; GUSMÃO, M.R.; GALVAN, T.L. Manejo integrado de pragas de hortaliças. In: Zambolim, L. (Ed.). Manejo integrado de doenças, pragas e ervas daninhas. Viçosa: UFV, p.275-324, 2000.

PICANÇO, M.C. et al. Yield loss in trellised tomato affected by insecticidal sprays and plant spacing. Crop Protection, v.17, n.5, p.447-452, 1998.

PRICE, P.W. The plant vigor hypothesis and herbivore attack. Oikos, v.62, n.2, p.8, 1991.

ROBERTSON, J.L. et al. Bioassays with Arthropods. 2nd ed., Boca Raton: CRC, 2007, 199p.

SALAZAR, E.R.; ARAYAJ.E. Detección de resistencia a insecticidas en la polilla del tomate. Simiente, v.67, p.822, 1997.

SALAZAR, E.R.; ARAYA, J.E. Respuesta de la polilla del tomate, Tuta absoluta (Meyrick), a insecticidas en Arica. Agricultura Técnica, v.61, n.4, p.429-435, 2001.

SAS Institute, SAS User's Guide: Statistics, Version 8.2. SAS Institute, Cary, NC 2001.

SILVA, D. J. H. D. ; VALE, F. X. R. D. Tomate: tecnologia e produção. Viçosa: UFV, v.1. 2007.355 p.

SILVA, M.T.B.; COSTA, E.C.; BOSS, A. Control of Anticarsia gemmatalis Hübner (Lepidoptera: Noctuidae) larvae with insect growth regulators. Ciência Rural, v.33, n.4, 2003. 
SIQUEIRA, H.A.A. et al. Abamectin resistance and synergism in Brazilian populations of Tuta absoluta (Meyrick) (Lepidoptera: Gelechiidae). International Journal of Pest Management, v.47, n.4, p.247-251, 2000b.

SIQUEIRA, H.A.A.; GUEDES, R.N.C.; PICANÇO, M.C. Insecticide resistance in populations of Tuta absoluta (Lepdoptera: Gelechiidae).

Agricultural and Forest Entomology, v.2, n.2, p.147-153, 2000a.
TRAN, D,H; MASAMI TAKAGI, M.; KAKASU, K. Toxicity of selective insecticides to Neochrysocharis formosa (Westwood) (Hymenoptera: Eulophidae), a parasitoid of the American serpentine leafminer Liriomyza trifolii (Burgess) (Diptera: Agrizomydae). Journal of the Faculty of Agriculture Kyushu University, v.50, n.1, p.109-118, 2005.

WANG, D. et al. Sublethal effects of spinosad on survival, growth and reproduction of Helicoverpa armigera (Lepidoptera: Noctuidae). Pest Management Science, v.65, n.2, p.223-227, 2009. 